\section{Anaesthetic manage- ment of the child with congenital heart disease for non-cardiac surgery}

Frederick A. Burrows MD FRCPC
The incidence of congenital heart disease (CHD) in North America remains constant at 8 per 1000 live births. ${ }^{1-3}$ Recent advances in diagnostic methods and in the surgical, anaesthetic and medical management of infants and children with CHD have profoundly affected survival patterns: increasing numbers of these children are surviving to adolescence and adulthood. ${ }^{4}$ In North America there are currently well over a half a million patients with congenital heart disease who have reached adulthood; each year at least 20,000 open heart operations are performed to repair congenital cardiac malformations. ${ }^{4}$

As survival rates increase, many children with repaired, palliated or unoperated congenital heart disease will undergo surgical procedures unrelated to their $\mathrm{CHD}$. Although their anaesthetic management is complicated by the diversity of congenital heart lesions, the approach to the child with CHD is the same whether the procedure is cardiac- or non-cardiac-related.

Although operations for CHD generally improve the patient's hemodynamic status, completely normal cardiovascular anatomy and physiology are rarely achieved (Table I). Palliated patients still present with distinctly abnormal circulations, but generally the severe consequences of CHD (severe congestive heart failure, severe hypoxaemia, polycythaemia and pulmonary vascular disease) do not pose major problems. Patients who have undergone surgical correction of CHD may still present with abnormal circulations. Arrhythmias, ventricular dysfunction, shunts, valvular stenosis or regurgitation and pulmonary hypertension may remain or develop after the surgical repair of CHD. The primary difference in noncardiac procedures is the difference in the surgical stresses that the patient experiences. Also, the involved surgeons frequently have little understanding of the individual child's particular lesion.

As a rule, patients with congenital heart disease who are doing well clinically (i.e., those who have good functional status and few or no medications, and are subject to routine medical attention) will do well if they require surgery. ${ }^{5}$ However, the following conditions should arouse concern in a preoperative setting: pulmonary arterial hypertension, severe aortic valvular or subvalvular stenosis, and uncorrected tetralogy of Fallot. Concern should also be raised by a history of recent congestive heart failure, recent unexplained syncope and substantial exercise intolerance, since failure to identify these higherrisk individuals with functional cardiac and pulmonary limitations imposed by $\mathrm{CHD}$ can result in avoidable cardiovascular problems during the perioperative period. ${ }^{6,7}$

An important aspect of the anaesthetic management of these patients is assessment by a qualified clinician who has detailed knowledge about the particular patient's lesion and functional status and the anticipated perioperative stresses.

This review will discuss the perioperative management of the child with impaired, palliated or repaired CHD and address some of the pathophysiological problems associated with the condition.

\section{Preoperative assessment}

The preoperative assessment of the child with CHD undergoing non-cardiac surgery should identify those individuals who are at higher risk because of the cardiac and pulmonary limitations imposed by their congenital cardiac lesion (Table II). The preoperative assessment should be complete enough to provide the anaesthetist with a clear understanding of the pathophysiology of the cardiac defect and the implications of any palliative or corrective procedures that have been performed. Consultation with the patient's cardiologist can provide information about any nuances in the particular patient's condition.

The history should emphasize the status of the cardiorespiratory system. Symptoms suggestive of congestive heart failure, activity intolerance, cyanosis or hypercyanotic episodes should be identified. A review of past and present medications provides some insight into the course of the patient's condition. Information about previous surgeries, both cardiac and non-cardiac, should provide important information about the patient's tolerance

From the Departments of Anaesthesia and Paediatrics (Division of Cardiology), The Hospital for Sick Children and the University of Toronto, Toronto, Ontario. 
TABLE I Efficacy of repairs for congenital heart disease

\begin{tabular}{|c|c|c|}
\hline True correction* & Correctiont & Palliation $\neq$ \\
\hline $\begin{array}{l}\text { Patient ductus } \\
\text { arteriosus }\end{array}$ & $\begin{array}{l}\text { Coarctation of } \\
\text { the aorta }\end{array}$ & Conduits \\
\hline \multirow[t]{4}{*}{ Atrial septal defect } & $\begin{array}{l}\text { Transposition of } \\
\text { the great arteries }\end{array}$ & Transplantation \\
\hline & $\begin{array}{l}\text { Ventricular septal } \\
\text { defect }\end{array}$ & Pulmonary atresia \\
\hline & Tetralogy of Fallot & Fontan operation \\
\hline & $\begin{array}{l}\text { Atrio-ventricular } \\
\text { septal defects }\end{array}$ & \\
\hline
\end{tabular}

*Results in normal life expectancy and normal cardiovascular reserve and requires no further medical or surgical treatment.

†Results in improved but not necessarily normal life expectancy and some limitation in cardiovascular reserve; may require further medical or surgical treatment.

$\Varangle$ Results in improved but not normal life expectancy and abnormal cardiovascular physiology; will require further medical or surgical therapy.

(Modified with permission from Hickey $P R$. Anesthesia for the reconstructed heart. In: Stoelting RK (Ed.). Advances in Anesthesia.

Chicago: Year Book Publishers 1991; 91-113.)

of perioperative stress, including that related to anaesthetic.

The physical examination characterizes the disease process and identifies related problems. It is important to determine if the child is active and thriving or frail and chronically ill. Examination of the respiratory system will reveal signs of respiratory distress, infection or associated anomalies and provide information about the adequacy of ventilatory function.

The extent of laboratory testing will depend on the type and extent of surgery planned. Pulmonary function testing may not be necessary for a child with tetralogy of Fallot undergoing outpatient myringotomies, but may provide important information about the need for postoperative ventilation after a posterior spinal fusion. ${ }^{8}$

An electrocardiogram can provide information about rate, rhythm, ventricular hypertrophy and ischaemia. Because changes are age-related, evaluation is usually best performed by a trained cardiologist.

The availability of recent echocardiographic and cardiac catheterization assessments can provide detailed information about the type and severity of the lesion, ventricular function, the status of the pulmonary vasculature and, if pulmonary hypertension is present, the response of the pulmonary vasculature to pulmonary vasodilators such as oxygen.

\section{Common problems in patients with CHD}

Perioperative risks can be reduced, often significantly, when the problems inherent in this patient population are
TABLE II Indices of critical impairment in congenital heart disease

Chronic hypoxaemia (arterial saturation $<75 \%$ )

Pulmonary to systemic blood flow ratio $>2: 1$

Left or right ventricular outflow tract gradient $>50 \mathrm{mmHg}$

Elevated pulmonary vascular resistance

Polycythaemia (haematocrit $>60 \%$ )

(Modified with permission from Hickey PR. Anesthesia for the reconstructed heart. In: Stoelting RK (Ed.). Advances in Anesthesia.

Chicago: Year Book Publishers 1991; 91-113.)

TABLE III Suggested management of severe hypoxaemia

\begin{tabular}{|c|c|c|}
\hline $\begin{array}{l}\text { Reduce pulmonary } \\
\text { vascular resistance }\end{array}$ & $\begin{array}{l}\text { Increase systemic } \\
\text { vascular resistance }\end{array}$ & $\begin{array}{l}\text { Reduce oxygen } \\
\text { consumption }\end{array}$ \\
\hline $100 \%$ oxygen & Phenylephrine & Sedation \\
\hline $\begin{array}{c}\text { Bilateral gas } \\
\text { exchange }\end{array}$ & $\begin{array}{l}\text { Manual abdominal } \\
\text { aörtic compression }\end{array}$ & $\begin{array}{l}\text { Mild hypothermia } \\
\left(32-35^{\circ} \mathrm{C}\right)\end{array}$ \\
\hline Hyperventilation & & General anaesthesia \\
\hline Mild PEEP & & Muscle paralysis \\
\hline $\begin{array}{l}\text { Negative inotrope if } \\
\text { tetralogy spell }\end{array}$ & & \\
\hline
\end{tabular}

(Modified with permission from Hickey PR. Anesthesia for the reconstructed heart. In: Stoelting RK (Ed.). Advances in Anesthesia.

Chicago: Year Book Publishers 1991; 91-113.)

identified. Congenital heart disorders produce only a limited number of problems that reduce cardiopulmonary reserve. 9,10 .

\section{Bacterial endocardial prophylaxis}

Most patients with CHD will be at risk of developing infective endocarditis and should receive appropriate prophylaxis, depending on the nature of the planned procedure. $^{11,12}$

\section{Paradoxical emboli}

Cyanotic patients are particularly prone to paradoxical emboli because of their venoarterial shunting. Air filters should be used in all intravenous lines, and extra precautions should be taken against venous thromboemboli. ${ }^{9}$

\section{Cyanosis (hypoxaemia)}

Cyanosis in the patient with CHD is due either to insufficient pulmonary blood flow in the presence of intracardiac shunting (e.g., tetralogy of Fallot) or to complete arterial/venous mixing of blood (e.g., transposition of the great arteries). Management of the onset of hypoxaemia in the perioperative setting is summarized in Table III. The cyanotic patient manifests problems related to their adaptation to chronic hypoxaemia. These adaptations include polycythaemia, neovascularization, increased blood volume and alterations in oxygen uptake and ventilation during stress. 
When CHD is associated with hypoxaemia, erythropoietin levels increase and secondary erythrocytosis ensues. The increased erythrocyte mass may resolve the deficit in tissue oxygenation and establish a new equilibrium at a higher haematocrit, but an excessive increase $(>60 \%)$ in erythrocyte mass can impair tissue oxygen delivery because of increased blood viscosity. ${ }^{13}$ Iron deficiency in such children also affects blood viscosity considerably since, in contrast to normal biconcave erythrocytes, iron-deficient erythrocytes are relatively rigid microspheres, resisting deformation in the microcirculation and thus increasing blood viscosity. ${ }^{14}$

Unlike the adult patient in whom erythrocytosis does not appear to be a risk factor for stroke, even when the haematocrit is $>65 \%,{ }^{15}$ renal and cerebral thrombosis do occur in cyanotic infants and young children with equally elevated haematocrits, particularly if they become dehydrated. ${ }^{16}$ Patients who have had previous thrombotic episodes should have a neurological assessment before surgery to document fully the extent of any existing neurological deficits. Polycythaemic patients require intravenous hydration from the time of the establishment of preoperative fasting until adequate oral intake is resumed postoperatively.

Coagulopathies may be present in cyanotic patients. ${ }^{17,18}$ Although the mechanisms responsible for this haemorrhagic disorder remain poorly defined, the severity of the bleeding diathesis does seem to correlate with the degree of erythrocytosis, especially in patients with haematocrits $>65 \% .{ }^{13} \mathrm{Abnormalities} \mathrm{of} \mathrm{the} \mathrm{prothrombin} \mathrm{time} \mathrm{and} \mathrm{partial}$ thromboplastin time may be present in patients with haematocrit values $>55 \%$, solely because of the erythrocytosis. The amount of anticoagulant added to the tubes in which the blood is collected must therefore be adjusted. Thrombocytopenia may be present; specific deficiencies of several coagulation factors, such as fibrinogen, have been reported. ${ }^{18-20}$

Preoperative phlebotomy without quantitative volume replacement is potentially hazardous. However, with appropriate volume replacement, children whose haematocrits exceed $60 \%$ may benefit from erythropoiesis since it will decrease the risk of thrombosis and reduce the bleeding tendency. When factor deficiencies are evident, fresh frozen plasma should be used for volume replacement. ${ }^{13}$

\section{Excessive pulmonary blood flow}

Excessive pulmonary blood flow results in both cardiac and pulmonary effects. The increased cardiac output necessary to maintain a normal systemic flow produces a volume overload on the ventricle that reduces cardiac reserve. The increased pulmonary artery pressure and flow have several effects on ventilation. The increase in pul- monary flow can enlarge pulmonary vessels, obstructing large and small airways. The increase in pulmonary venous return can increase left atrial volume and pressure. The enlarged left atrium can obstruct the left mainstem bronchus; the increase in left atrial pressure can produce pulmonary venous congestion with increased interstitial and alveolar water. ${ }^{21}$ This condition may manifest as decreased pulmonary compliance, resulting in increased work of breathing, tachypnoea and wheezing. ${ }^{22}$

Over time, increased pulmonary blood flow and pressure will produce pulmonary vascular occlusive disease. The speed of its development depends upon the degree to which flow and pressure are increased and also on genetic factors. The reversibility of the abnormality is dependent upon the extent of pathological change when pulmonary flow and pressure are reduced to normal. ${ }^{23}$

\section{Ventricular dysfunction}

Congestive heart failure develops because of an increased pressure or volume load on the heart. Cardiovascular reserve is decreased and pulmonary congestion is often present, thus increasing the work of breathing. Because the increased work of breathing increases caloric demands while making feeding difficult, patients frequently demonstrate failure to thrive. The additional stress of anaesthesia and surgery may be sufficient to produce cardiac decompensation. The reversibility of the ventricular dysfunction is variable and depends upon the correctability of the defect and the duration of the ventricular dysfunction. ${ }^{24}$

\section{Arrhythmias}

Arrhythmias present in patients with CHD can be of congenital or iatrogenic origin or may result from the disease process itself. ${ }^{25,26}$ Such arrhythmias may limit cardiovascular reserve and increase perioperative risk. Iatrogenic causes in the perioperative period are many and may be due to the anaesthetic agent or chronic cardiac medications. These patients may be taking chronic anti-arrhythmic medications or suffer electrolyte abnormalities because of current drug regimens. Patients with a congenital or iatrogenic heart block may have a permanent pacemaker or may benefit from the insertion of a temporary pacemaker for the perioperative period. ${ }^{26}$

\section{Left ventricular outflow obstruction}

Patients with left ventricular outflow obstruction (Table IV) may present with a history of syncope, fatigue, or dysrhythmias or chest pain or both. ${ }^{27}$ Further evaluation may reveal evidence of left ventricular hypertrophy or ischaemia. These patients have decreased left ventricular reserve and may be at risk for developing ventricular fibrillation because of the precarious myocardial oxygen 
TABLE IV Obstructions to left and right ventricular outflow

\begin{tabular}{ll}
\hline Left heart oufflow & Right heart outflow \\
\hline Internipted aortic arch & Pulmonary artery stenosis \\
Coarctation of the aorta & Pulmonary vascular occlusive \\
& disease \\
Aortic stenosis (subvalvular, & Pulmonary stenosis (valvular, \\
valvular, supravalvular) & subvalvular, supravalvular) \\
Mitral stenosis and atresia & Tetralogy of Fallot \\
Hypoplastic left heart syndrome & Pulmonary atresia \\
\hline
\end{tabular}

supply-to-demand ratio. ${ }^{28}$ Management is aimed at maintaining coronary perfusion pressure and the ventricle's inotropic state. Vasopressor and inotropic support may be required.

\section{Right ventricular outflow obstruction}

Right ventricular outflow obstruction may occur at multiple levels (Table IV). Patients with this defect may have a hypertensive, hypertrophied right ventricle that is subject to ischaemia. ${ }^{27}$ The presence of an intra-cardiac defect may serve as a vent when right-sided pressure exceeds leftsided pressure as occurs in patients with Eisenmenger's syndrome. $^{23}$ The aim of management is to maintain coronary perfusion pressure to the right ventricle and the ventricular inotropic state. Reduction of right ventricular afterload can be beneficial. Pulmonary hypertension in patients with pulmonary vascular occlusive disease is a high-risk situation. ${ }^{23,29}$ These patients are subject to sudden, acute elevations in pulmonary vascular resistance, which can result in acute right ventricular failure. ${ }^{29}$ Management of elevated pulmonary vascular resistance is outlined in Table III.

\section{Myocardial ischaemia}

The aetiology of myocardial ischaemia in children with congenital cardiac disorders is multifactorial. ${ }^{28}$ As in adults, atherosclerosis in children may occur in several situations: in certain congenital disorders of lipid metabolism $^{30}$ and progeria ${ }^{31,32}$ or after cardiac transplantation. ${ }^{33}$ In general, however, myocardial ischaemia occurs both in children with hypoperfused lesions (e.g., hypoplastic left heart syndrome), with decreased coronary perfusion and flow, and in those with defects with chronic hypoxaemia (cyanotic lesions). ${ }^{34-37}$ The end result, as in adults, is an imbalance in oxygen supply and demand ${ }^{38}$ Isolated right ventricular ischaemia occurs more often in children because of the high occurrence of right-sided cardiac abnormalities.

Treatment of the ischaemic failing left ventricle is similar to that in adults with afterload reduction and inotropic support. When isolated right ventricular ischaemia is treated, early therapeutic considerations should include increasing coronary perfusion pressure with vasopressors and optimization of preload. ${ }^{28}$

\section{Response to stress}

In cyanotic patients, the presence of intra-cardiac mixing or shunting dissociates the right and left circulations, making dynamic coupling of cellular and pulmonary gas exchange inefficient or impossible. These patients demonstrate a slow adaptation to changes in metabolic rate, which imposes an abnormal dependence on non-oxidative metabolism. ${ }^{39.40}$ It is not surprising, therefore, that cyanotic patients tend to develop a respiratory as well as a metabolic acidosis in response to perioperative stress, a condition which may result in a prolongation of adaptation to and recovery from even low levels of perioperative stress. ${ }^{41-43}$

\section{Anaesthetic management}

\section{Premedication}

Premedication has been recommended for children with CHD to minimize the anxiety of parental separation so that the patient will be calm and sedated on arrival in the operating room. The patient's demand for oxygen is thus minimized, but it is not so obtunded as to cause hypoventilation. This control is particularly important in cyanotic children since increased anxiety can produce marked desaturation. Although premedicating children with $\mathrm{CHD}$ is considered to be safe, ${ }^{44.45}$ some heavily premedicated patients with cyanotic CHD have demonstrated large decreases in arterial saturation when left unstimulated, ${ }^{44}$ possibly because of their decreased respiratory response to hypoxia. ${ }^{46}$ Consequently, these patients require close monitoring and supplemental oxygen when heavy premedication is administered. ${ }^{44}$

\section{Monitoring}

The site of blood pressure monitoring lines can be influenced by previous surgery. The blood pressure of children who have undergone previous placement of a BlalockTaussig shunt or coarctation repair should not be monitored in the arm on the side of the repair because of the potential distortion of the subclavian artery. Similarly, in children who have undergone previous coarctation repair, distal blood pressure monitoring may underestimate the arterial pressure present above the surgical site if a residual stenosis and gradient are present.

These patients' basic monitoring needs are those prescribed by the Canadian Anaesthetists' Society. ${ }^{47}$ Potential inaccuracies are associated with the use of pulse oximeters in children with cyanotic CHD. ${ }^{48,49}$ For patients with haemoglobin saturations $<80 \%$, many pulse oximeters overestimate whereas others underestimate arterial oxygen 
saturation. ${ }^{48,49}$ These effects are dependent upon the model of the pulse oximeter. The type of haemoglobin present in the patient also affects the accuracy of the pulse oximeter. In neonates and infants the presence of $\mathrm{HbF}$ overestimates the true arterial haemoglobin oxygen saturation.

End-tidal $\mathrm{PCO}_{2}$ provides an accurate estimate of arterial $\mathrm{CO}_{2}$ partial pressure $\left(\mathrm{PaCO}_{2}\right)$ in acyanotic children with $\mathrm{CHD}$, but has significantly underestimated $\mathrm{PaCO}_{2}$ in children with cyanotic CHD. ${ }^{50,51}$

\section{Anaesthetic techniques}

Although most children with CHD tolerate a well-managed anaesthetic, their ability to tolerate any perioperative stresses associated with major anaesthetic and surgical insults is reduced.

No single anaesthetic technique can be recommended for children with CHD. Studies have demonstrated that well-managed general or regional anaesthesia can be used safely in any individual patient with $\mathrm{CHD}{ }^{6,7,52,53}$ The technique must be tailored to the individual patient to account for decreases in cardiovascular reserve and to anticipate potential problems.

\section{Conclusion}

Most children with congenital heart disease can be managed safely if the pathophysiology of their lesion and the anaesthetic implications are understood. ${ }^{5}$ However, recent reviews of anaesthetic morbidity reveal a high incidence of anaesthetic-related adverse events in children with congenital heart disease. ${ }^{6.7}$

\section{Acknowledgement}

This paper was prepared with the assistance of Medical Publications, The Hospital for Sick Children, Toronto, Ontario.

\section{References}

1 Fyler DC. Report of the New England regional infant cardiac program. Pediatrics 1980; 65 (suppl): 375-461.

2 Nadas AS, Fyler DC. Pediatric Cardiology. 3rd ed. Philadelphia: WB Saunders 1972.

3 Hoffman JIE, Christianson R. Congenital heart disease in a cohort of 19,502 births with long-term follow-up. Am J Cardiol 1978; 42: 641-7.

4 Perloff JK. (Conference Chairman). Congenital heart disease after childhood: an expanding patient population. 22nd Bethesda Conference, Bethesda MD, Oct. 18-19, 1990. J Am Coll Cardiol 1991; 18: 311-42.

5 Hickey PR, Hansen DD, Norwood WI, Castaneda $A R$. Anesthetic complications in surgery for congenital heart disease. Anesth Analg 1984; 63: 657-64.

6 Strafford MA, Henderson $K H$. Anesthetic morbidity in congenital heart disease patients undergoing non-cardiac surgery (abstract). Anesthesiology 1991: 75; A1056.
7 Strafford MA, Henderson $K H$. Anesthetic morbidity in congenital heart disease patients undergoing outpatient surgery (abstract). Anesthesiology 1991; 75: A866.

8 Dobbinson TL, Gray IG, Nisbet HIA, Pelton DA, Levison $H$, Volgyesi $G$. Thoracic compliance and lung volumes in children with heart disease. Acta Anaesthesia Scand 1973; 17: 50-6.

9 Webb GD, Burrows FA. The risks of noncardiac surgery. J Am Coll Cardiol 1991; 18: 323-5.

10 Hickey PR, Streitz S. Preoperative assessment of the patient with congenital heart disease. In: Mangano DT (Ed.). Preoperative Cardiac Assessment. Philadelphia: JB Lippincott 1990; 85-123.

11 Dajani AS, Bisno AL, Chung KJ, et al. Prevention of bacterial endocarditis. Recommendations by the American Heart Association. JAMA 1990; 264: 2919-22.

12 Child JS. Infective endocarditis: risks and prophylaxis. J Am Coll Cardiol 1991; 18: 337-8.

13 Territo $M C$, Rosove $M H$. Cyanotic congenital heart disease: hematologic management. J Am Coll Cardiol 1991; 18: 320-2.

14 Linderkamp O, Klose HJ, Betke K, et al. Increased blood viscosity in patients with cyanotic congenital heart disease and iron deficiency. J Pediatr 1979; 95: 567-9.

15 Perloff $J K$, Rosove $M H$, Child $J S$, Wright $G B$. Adults with cyanotic congenital heart disease: hematologic management. Ann Intern Med 1988: 109: 406-13.

16 Phornphutkul C, Rosenthal A, Nadas AS, Berenberg $W$. Cerebrovascular accidents in infants and children with cyanotic congential heart disease. Am J Cardiol 1973; 32: 329-34.

17 Henriksson $P$, Värendh $G$, Lundström $N-R$. Hemostatic defects in cyanotic congenital heart disease. Br Heart J 1979: 41: 23-7.

18 Coló-Otero G, Gilchrist GS, Holcomb GR, Ilstrup DM, Bouie EJW. Preoperative evaluation of hemostasis in patients with congenital heart disease. Mayo Clin Proc 1987; 62: 379-85.

19 Ekert H, Gilchrist GS, Stanton R, Hammond D. Hemostasis in cyanotic congenital heart disease. J Pediatr 1970; 76: 221-30.

20 Wedemeyer AL, Edson JR, Krivit W. Coagulation in cyanotic congenital heart disease. Am J Dis Child 1972; 124: 656-60.

21 Stanger $P$, Lucas $R V J r$, Edwards JE. Anatomic factors causing respiratory distress in acyanotic congenital cardiac disease. Special reference to bronchial obstruction. Pediatrics 1969: 43: 760-9.

22 Shulman DL, Burrows FA, Poppe DJ, Smallhorn JS. Perioperative respiratory compliance in children undergoing repair of atrial septal defects. Can J Anaesth 1991; 38: 292-7.

23 Burrows FA, Rabinovitch $M$. The pulmonary circulation in children with congenital heart disease: morphologic and 
morphometric considerations. Can Anaesth Soc J 1985; 32: 364-73.

24 Dreyer WJ. Congestive heart failure. In: Garson A Jr. Bricker JT, McNamara DG (Eds.). The Science and Practice of Pediatric Cardiology. Vol. III. Philadelphia: Lea and Febiger 1990: 2007-23.

25 Kugler JD, Danford DA. Pacemakers in children: an update. Am Heart J 1989; 117: 665-79.

$26 O^{\prime}$ Gara JP, Edelmann JD. Anesthesia and the patient with complete congenital heart block. Anesth Analg 1981; 60: 906-8.

27 Adams FH, Emmanouilides GC, Reimenschneider $T A$. Moss' heart disease in infants, children, and adolescents. Baltimore: Williams and Wilkins 1989.

28 Greeley WG. Myocardial ischemia and congential heart disease. Anesthesiology Report 1988: 1: 200-4.

29 Burrows FA, Klinck JR, Rabinovitch M, Bohn $D J$. Pulmonary hypertension in children: perioperative management. Can Anaesth Soc J 1986: 33: 606-28.

30 Bricker JT, Blumenschein SD. Systemic hypertension and preventive cardiology. In: Garson A Jr, Bricker JT, McNamara DG (Eds.). The Science and Practice of Pediatric Cardiology. Voi. III. Philadelphia: Lea and Febiger 1990; 1987-95.

31 Rosenbloom AL, DeBusk FL. Progeria of HutchinsonGilford: a caricature of aging. Am Heart J 1971; 82: 287-9.

32 Chapin JW, Kahre J. Progeria and anesthesia. Anesth Analg 1979; 58: 424-5.

33 Frazier $O H$, Macris MP. Pediatric cardiac transplantation. In: Garson A Jr, Bricker JT, McNamara DG (Eds.). The Science and Practice of Pediatric Cardiology. Vol. III. Philadelphia: Lea and Febiger 1990: 2227-38.

34 Silverman NA, Kohler J, Lenitsky S, Panel DG, Fang RB, Feinberg $H$. Chronic hypoxemia depresses global ventricular function and predisposes to the depletion of high-energy phosphates during cardioplegic arrest: implications for surgical repair of cynotic congenital heart defects. Ann Thorac Surg 1984: 37: 304-8.

35 Kohler J, Silverman NA, Levitsky S, Pavel DG, Eckner FA, Fantg RB. A model of cyanotic heart disease: functional, pathological, and metabolic sequelae in the mature canine heart. J Surg Res 1984; 37: 309-13.

36 Young HH, Shimizu T, Nishioka $K$, Nakanishi $T$, Jarmakani $M$. Effect of hypoxia and reoxygenation on mitochondrial function in neonatal myocardium. Am J Physiol 1983; 245: H998-1006.

37 Yeager $S B$, Freed $M D$. Myocardial infarction as a manifestation of polycythemia in cyanotic heart disease. Am J Cardiol 1984: 53: 952-3.

38 Graham TP Jr. Ventricular performance in adults after operation for congenital heart disease. Am J Cardiol 1982; 50: $612-20$.
39 Sietsema KE, Cooper DM, Perloff JK, et al. Dynamics of oxygen uptake during exercise in adults with cyanotic congenital heart disease. Circulation 1986; 73: 1137-44.

40 Sietsema KE, Cooper DM, Perloff JK, et al. Control of ventilation during exercise in patients with central venous to systemic arterial shunts. J Appl Physiol 1988; 64: 234-42.

41 Drakonakis AC, Halloran $K H$. Oxygen consumption during recovery from exercise in children with congenital heart disease. Am J Dis Child 1974: 128: 651-6.

42 Davies $H$, Gazetopoulos $N$. Dyspnoea in cyanotic heart disease. Br Heart J 1965; 27: 28-41.

43 Eriksson $B O$, Bjarke $B$. Oxygen uptake, arterial blood gases and blood lactate concentration during submaximal and maximal exercise in adult subjects with shunt-operated tetralogy of Fallot. Acta Med Scand 1975; 197: 187-93.

44 De Bock TL, Petrilli RL, Davis PJ, Motoyama EK. Effect of premedication on preoperative arterial oxygen saturation in children with congenital heart disease (abstract). Anesthesiology 1987; 67: A492.

45 Stow PJ, Burrows FA, Lerman J, Roy WL. Arterial oxygen saturation following premedication in children with cyanotic congential heart disease. Can J Anaesth 1988; 35 63-6.

46 Edelman NH, Lahiri S, Braudo L, Cherniack NS, Fishman $A P$. The blunted ventilatory response to hypoxia in cyanotic congenital heart disease. N Engl J Med 1970; 282: 405-11.

47 Guidelines to the practice of anaesthesia as recommended by the Canadian Anaesthetists' Society. Toronto: Canadian Anaesthetists' Society, 1989.

48 Severinghaus $J W$, Naifeh $K H$. Accuracy of response of six pulse oximeters to profound hypoxia. Anesthesiology 1987; 67: 551-8.

49 Tremper KK, Barker SJ. Pulse oximetry. Anesthesiology 1989; 70: 98-108.

50 Burrows FA. Physiological dead space, venous admixture, and the arterial to end-tidal carbon dioxide difference in infants and children undergoing cardiac surgery. Anesthesiology 1989; 70: 219-25.

51 Lazzell VA, Burrows FA. Stability of the intraoperative arterial to end-tidal carbon dioxide partial pressure difference in children with congenital heart disease. Can J Anaesth 1991; 38: 859-65.

52 Laishley RS, Burrows FA, Lerman J, Roy WL. Effect of anesthetic induction regimens on oxygen saturation in cyanotic congenital heart disease. Anesthesiology 1986: 65: 673-7.

53 Greeley WJ, Bushman GA, Davis DP, Reves JG. Comparative effects of halothane and ketamine on systemic arterial oxygen saturation in children with cyanotic heart disease. Anesthesiology 1986; 65: 666-8. 


\section{Conduite de l'anesthésie pour la chirurgie non- cardiaque chez l'enfant porteur de maladie cardiaque congénitale}

Frederick A. Burrows MD FRCPC
L'incidence de maladie cardiaque congénitale en Amérique du Nord demeure stable et de l'ordre de 8 pour 1000 naissances vivantes. ${ }^{1-3}$ Les progrès récents du diagnostic et de la conduite chirurgicale, anesthésique et médicale des enfants et des nouveau-nés porteurs de maladies cardiaques congénitales ont profondément modifié la survie : un nombre croissant de ces enfants vont survivre jusqu'à l'adolescence et l'âge adulte. ${ }^{4}$ En Amérique du Nord il y a actuellement au-delà d'un demi million de patients avec maladies cardiaques congénitales qui ont atteint l'âge adulte; chaque année il y a au moins 20000 opérations à coeur ouvert pratiquées pour corriger ces dites malformations. ${ }^{4}$

À mesure que le taux de survie s'améliore, plusieurs enfants avec malformations cardiaques congénitales soumis ou non à une chirurgie correctrice ou palliative, auront à subir d'autres interventions sans relation avec leur maladie congénitale. Même si la conduite de l'anesthésie est compliquée par la diversité des lésions congénitales, l'évaluation de l'enfant avec maladie cardiaque congénitale (MCC) est la même, que la procédure envisagée soit cardiaque ou non cardiaque.

Même si les interventions pour MCC améliorent en général l'état hémodynamique du patient, l'anatomie et la physiologie cardiovasculaires redeviennent rarement complètement normales (Tableau I). Ceux soumis antérieurement à une chirurgie palliative vont encore avoir des anomalies de la circulation, mais habituellement les conséquences sévères de la maladie cardiaque congénitale (insuffisance cardiaque sévère, hypoxémie sévère, polycythémie et maladie vasculaire pulmonaire) ne causent plus de problèmes importants. Les patients qui ont bénéficié d'une correction chirurgicale de leur MCC peuvent encore faire montre d'anomalies de la circulation.

Ainsi, les dysrythmies, la dysfonction ventriculaire, les shunts, les sténoses et régurgitations valvulaires, et l'hypertension pulmonaire peuvent se développer ou persister après la correction chirurgicale de la MCC. La différence principale entre les interventions cardiaques et non-cardiaques résident dans la différence dans le niveau de stress vécu chez le patient. De plus, les chirurgiens impliqués dans la chirurgie non-cardiaque ont souvent une faible compréhension des lésions de leur patient.

De façon générale, les patients avec MCC qui vont bien cliniquement (i.e., ceux qui ont une bonne classe fonctionnelle, peu ou pas de médication, et sont sujets à des évaluations de routine) ne présenteront pas de difficultés $s^{\prime}$ 'ils requièrent de la chirurgie. ${ }^{5}$ Cependant, les conditions suivantes devraient attirer l'attention lors de l'évaluation préopératoire : hypertension artérielle pulmonaire, sténose aortique sévère valvulaire ou sous-valvulaire, et tétralogie de Fallot non corrigée. L'on devra porter aussi attention aux histoires récentes d'insuffisance cardiaque congestive, de syncope récente inexpliquée, et d'intolérance marquée à l'exercice, puisque les erreurs de dépistage de patients à haut risque, avec limitations cardiaques et pulmonaires fonctionnelles imposées par leur MCC, pourront conduire à des problèmes cardio-vasculaires évitables pendant la période périopératoire. 6,7

Un aspect important de la conduite anesthésique chez ces patients est l'évaluation par un clinicien qualifié, avec une connaissance détaillée des lésions, du statut fonctionnel, et du stress périopératoire anticipé chez chaque patient.

Ce cours reverra la conduite périopératoire de l'enfant avec $\mathrm{MCC}$ opérée ou non-opérée, et s'intéressera à quelques uns des problèmes physio-pathologiques associés à la condition citée.

\section{Évaluation préopératoire}

L'évaluation préopératoire des enfants avec MCC soumis à une chirurgie non-cardiaque, devrait porter l'accent sur le dépistage de ceux qui sont à haut risque, à cause des limitations cardiaques et pulmonaires imposées par leur lésions cardiaques congénitales (Tableau II). L'évaluation préopératoire devrait être suffisamment complète pour donner à l'anesthésiste un tableau clair de la pathophysiologie de la lésion cardiaque et de l'importance des procédures correctives ou palliatrices déjà faites dans le passé. La consultation avec le cardiologue du patient peut 
TABLEAU I Efficacite de la chirurgie corrective des malformations cardiaques congénitales

\begin{tabular}{|c|c|c|}
\hline Correction véritable* & Correctiont & Paliation $\neq$ \\
\hline \multirow{4}{*}{$\begin{array}{l}\text { Canal artériel perméable } \\
\text { Communication inter- } \\
\text { auriculaire }\end{array}$} & Coarctation de l'aorte & Transplantation \\
\hline & $\begin{array}{c}\text { Transposition des } \\
\text { gros vaisseaux }\end{array}$ & Conduit \\
\hline & $\begin{array}{l}\text { Communication inter- } \\
\text { ventriculaire }\end{array}$ & Atrésie pulmonaire \\
\hline & $\begin{array}{l}\text { Tétralogie de Fallot } \\
\text { Sténose valvulaire } \\
\text { Anomalies de paroi } \\
\text { auriculo-ventriculaire }\end{array}$ & Opération de Fontan \\
\hline
\end{tabular}

*Amène une espérance de vie normale, une réserve cardiovasculaire normale, ne demande pas d'autre traitement médical ou chirurgical. †Améliore l'espérance de vie ( $\not$ normale), avec limitation possible de la réserve cardiovasculaire, peut requérir un traitement médical et chirurgical subséquent.

¥Améliore l'espérance de vie sans la rendre normale et sans redonner une physiologie cardio-vasculaire normale. Nécessitera un traitement médical ou chirurgical subséquent.

(Modifié avec permission de Hickey PR. Anesthesia for the reconstructed heart. Dans : Stoelting RK (Ed.). Advances in Anesthesia. Chicago, Year Book Publishers, 1991 ; 91-113.)

TABLEAU II Indices d'atteinte critique dans la maladie cardiaque congénitale

Hypoxémie chronique (saturation artérielle $<75 \%$ )

Rapport débit pulmonaire/systémique $>2: 1$

Gradient d'éjection droit ou gauche $>50 \mathrm{mmHg}$

Résistance vasculaire pulmonaire élevée

Polycythémie (hématocrite $>60 \%$ )

(Modifié avec permission de Hickey $P R$. Anesthesia for the reconstructed heart. Dans: Stoelting RK (Ed.). Advances in Anesthesia. Chicago, Year Book Publishers, 1991 ; 91-113.)

apporter une information sur les particularités propres de la maladie de la personne évaluée.

L'histoire devrait porter l'accent sur l'état de la fonction cardio-respiratoire. On tentera d'identifier les symptômes suggestifs d'insuffisance cardiaque congestive, d'intolérance à l'activité, de cyanose ou d'épisodes hyper-cyanotiques. Une revue de la médication actuelle et antérieure pourra donner une idée de l'évolution de la maladie du patient. L'histoire chirurgicale, autant que cardiaque que non-cardiaque, devrait être la source d'une information d'importance sur la tolérance du patient au stress périopératoire, incluant celui directement relié à l'anesthésie.

L'examen physique reflètera l'évolution de la maladie et identifiera les problèmes associés. Il est important de savoir si l'enfant est actif et en pleine croissance ou s'il est frêle et malade chronique. L'examen du système respiratoire mettra en évidence les signes de détresse respiratoire, d'infection ou d'anomalie associée et informera sur la qualité de la ventilation.
L'importance de l'évaluation par épreuves de laboratoire dépendra du type et de l'importance de la chirurgie envisagée. On pourra éviter les épreuves de fonction respiratoire chez l'enfant avec tétralogie de Fallot soumis à une myringotomie sur une base ambulatoire, mais ces épreuves pourront être très utiles pour déterminer les besoins de ventilation postopératoire après une fusion spinale postérieure. ${ }^{8}$

L'électrocardiogramme apportera de l'information sur la fréquence et le rythme cardiaque, l'hypertrophie ventriculaire et l'ischémie. Puisque les changements à l'ECG varient selon l'âge, il est préférable de faire évaluer l'ECG par un cardiologue expérimenté.

La disponibilité récente de l'évaluation par échocardiographie et cathétérisme cardiaque, peut amener une information détaillée sur le site et la sévérité de la lésion, sur la fonction ventriculaire, l'état de la vascularisation pulmonaire, et s'il y a hypertension pulmonaire, sur la réponse de la vascularisation pulmonaire aux vasodilatateurs pulmonaires tels l'oxygène.

\section{Problèmes courants chez les patients avec $\mathrm{MCC}$}

Les risques périopératoires peuvent être réduits souvent de façon significative, lorsque des problèmes particuliers à cette population sont identifiés. Les maladies cardiaques congénitales sont responsables d'un nombre limité de problèmes qui pourront réduire la réserve cardio-pulmonaire. ${ }^{9,10}$

\section{Prophylaxie de l'endocardite bactérienne}

La plupart des patients avec MCC risqueront de présenter une endocardite infectieuse et devraient recevoir une prophylaxie adéquate, en fonction de la nature de l'intervention envisagée. ${ }^{11,12}$

\section{Embolie paradoxale}

Les patients cyanotiques sont particulièrement susceptibles aux embolies paradoxales à cause du shunt veino-artériel. Toutes les lignes intraveineuses devraient être munies de filtres pour bulles d'air, et l'on doit prendre des précautions supplémentaires pour prévenir les thrombo-embolies veineuses. ${ }^{9}$

\section{Cyanose (hypoxémie)}

La cyanose chez les patients avec MCC est due soit à une circulation pulmonaire insuffisante en présence d'un shunt intra-cardiaque (e.g., tétralogie de Fallot) ou à un mélange incomplet du sang artériel et veineux (e.g., transposition des gros vaisseaux). La conduite à adopter en face d'une hypoxémie dans la période périopératoire est résumée dans le Tableau III. Le patient cyanosé aura des problèmes reliés à son adaptation à l'hypoxémie chronique. Cette adaptation inclut la polycythémie, une néovascularisation, 
TABLEAU III Traitement suggéré de l'hypoxémie sévère

\begin{tabular}{|c|c|c|}
\hline $\begin{array}{l}\text { Diminuer la } \\
\text { résistance } \\
\text { vasculaire } \\
\text { pulmonaire }\end{array}$ & $\begin{array}{l}\text { Augmenter la } \\
\text { résistance } \\
\text { vasculaire } \\
\text { systémique }\end{array}$ & $\begin{array}{l}\text { Diminuer la } \\
\text { consommation } \\
\text { d'oxygène }\end{array}$ \\
\hline $\begin{array}{l}\text { Oxygène } 100 \% \\
\text { Échange bilatéral } \\
\quad \text { de gaz } \\
\text { Hyperventilation } \\
\text { PEEP modéré } \\
\text { Inotropes négatifs } \\
\text { épisode de tétra }\end{array}$ & $\begin{array}{l}\text { Phénylephrine } \\
\text { Compression manuelle } \\
\text { abdominale de l'aorte }\end{array}$ & $\begin{array}{l}\text { Sédation } \\
\text { Hypothermie modérée } \\
\quad\left(32-35^{\circ} \mathrm{C}\right) \\
\text { Anesthésie générale } \\
\text { Paralysie musculaire }\end{array}$ \\
\hline
\end{tabular}

(Modifié avec permission de Hickey PR. Anesthesia for the reconstructed heart. Dans: Stoeiting RK (Ed.). Advances in Anesthesia. Chicago, Year Book Publishers, 1991 ; 91-113.)

une augmentation du volume sanguin circulant et des changements dans la captation d'oxygène et la ventilation durant le stress.

Lorsque la MCC s'associe à une hypoxémie, le niveau d'érythropoiétine augmente et il y a érythrocytose secondaire. L'augmentation de la masse des érythrocytes peut compenser le déficit en oxygénation tissulaire et établir un nouvel équilibre à une hématocrite plus élevée, mais une augmentation trop importante $(>60 \%)$ de la masse des globules rouges peut nuire à la livraison d'oxygène tissulaire à cause d'une viscosité sanguine augmentée. ${ }^{13}$ Un déficit en fer chez ces enfants va aussi modifier sérieusement la viscosité du sang puisque, contrairement aux érythrocytes normaux biconcaves, les globules rouges déficients en fer sont des microsphères relativement rigides, qui résistent à la déformation dans la microcirculation et donc augmentent ainsi la viscosité sanguine. ${ }^{14}$

À la différence de la population adulte chez laquelle l'érythrocytose ne semble pas être un facteur important d'embolisation, même si l'hématocrite est supérieure à $65 \%,{ }^{15}$ les thromboses cérébrales et rénales apparaissent chez les nourrisons et les enfants cyanosés porteurs d'hématocrites élevées de façon similaire, surtout s'ils deviennent déshydratés. ${ }^{16}$ Les patients qui ont eu des épisodes thrombotiques dans le passé devraient avoir une évaluation neurologique avant la chirurgie pour documenter complètement l'état des déficits neurologiques existants. Les patients polycythémiques ont besoin d'une hydratation veineuse à partir du début du jeûne préopératoire, jusqu'à ce que l'hydratation orale soit reprise dans la période postopératoire.

Certaines coagulopathies peuvent se manifester chez les patients cyanosés. ${ }^{17,18}$ Même si les mécanismes responsables pour ces problèmes hémorragiques demeurent mal définis, la sévérité de la diathèse hémorragique ne semble pas reliée au degré d'érythrocytose, surtout chez les patients avec des hématocrites au-delà de $65 \% .^{13}$ On retrouvera des anomalies du temps de prothrombine et du temps de thromboplastine partiel chez les patients avec des hématocrites au-delà de $55 \%$, simplement à cause de l'érythrocytose. Il faut dès lors ajuster la quantité d'anticoagulants dans les tubes de prélèvements sanguins. ll peut $y$ avoir une thrombocytopénie, et l'on a rapporté des déficits spécifiques de plusieurs facteurs de coagulation, tels le fibrinogène. ${ }^{18-20}$

La phlébotomie préopératoire sans remplacement adéquat du volume demeure possiblement dangereuse. Cependant, des enfants dont les hématocrites dépassent $60 \%$ pourront tirer un certain bénéfice de l'érythropoièse, s'il y a remplacement adéquat de volume, puisque cette procédure diminuera les risques de thrombose et de saignement. Lorsqu'il y a déficit de facteurs, le remplacement de volume devrait se faire à partir de plasma frais congelé. ${ }^{13}$

\section{Circulation sanguine pulmonaire excessive}

Une circulation pulmonaire excessive aura des effets autant cardiaques que pulmonaire. Le débit cardiaque augmenté nécessaire au maintien d'une circulation systémique normale occasionnera une surcharge de volume sur le ventricule droit, ce qui diminue la réserve cardiaque. L'augmentation de pression et de débit dans l'artère pulmonaire a de nombreux effets sur la ventilation. L'augmentation de débit peut dilater les vaisseaux pulmonaires, et amener une obstruction des voies aériennes, petites et grandes. L'augmentation du retour veineux pulmonaire peut accroitre la pression et le volume de l'oreillette gauche. L'oreillette gauche dilatée peut obstruer la bronche souche gauche; l'augmentation de pression dans l'oreillette gauche peut amener une congestion veineuse pulmonaire avec accumulation d'eau interstitielle et alvéolaire. ${ }^{21}$ Ceci se reflètera en une diminution de la compliance pulmonaire, avec comme conséquence une augmentation du travail respiratoire, de la tachypnée, et des sibilences. ${ }^{22}$

Avec le temps, l'augmentation de la pression et du débit sanguin pulmonaire produiront une maladie vasculaire occlusive pulmonaire. La vitesse de développement de cette entitée dépend du degré d'augmentation du débit et de la pression et aussi de facteurs génétiques. La réversibilité de l'anomalie va dépendre de l'étendue des changements pathologiques au moment où le débit et la pression pulmonaire sont ramenés à la normale. ${ }^{23}$

\section{Dysfonction ventriculaire}

L'insuffisance cardiaque congestive survient à cause d'une augmentation de pression ou d'une surcharge de volume au coeur. La réserve cardiovasculaire est diminuée et il y 
a souvent congestion pulmonaire, ce qui augmente le travail respiratoire. Puisque cette augmentation de travail accroît les besoins caloriques tout en rendant l'alimentation difficile, les patients ont souvent des troubles de croissance. Le stress surajouté de l'anesthésie et de la chirurgie peut être suffisant pour produire une décompensation cardiaque. La dysfonction ventriculaire est réversible de façon variable et dépend de la possibilité de corriger l'anomalie et aussi de la durée de la dysfonction ventriculaire. $^{24}$

\section{Dysrythmies}

Les dysrythmies présentes chez les patients avec MCC peuvent être d'origine congénitale ou iatrogénique ou encore résulter de la maladie elle-même. ${ }^{25,26}$ Ces dysrythmies peuvent limiter la réserve cardiovasculaire et augmenter le risque périopératoire. Les causes iatrogéniques présentes dans la période périopératoire sont nombreuses et peuvent dûes à l'agent anesthésique ou à la médication cardiaque administrée sur une base chronique. Ces patients peuvent consommer une médication antiarythmique ou faire preuve d'anomalies électrolytiques à cause de leur régime thérapeutique. Les patients avec bloc de conduction congénital iatrogénique peuvent déjà être porteurs d'un pacemaker permanent ou encore bénéficier de l'insertion d'un pacemaker temporaire pendant la période périopératoire. ${ }^{26}$

\section{Obstruction à l'éjection ventriculaire gauche}

Les patients avec obstruction à l'éjection ventriculaire gauche (Tableau IV) peuvent se présenter avec une histoire de syncope, de fatigue, ou de dysrythmies avec ou sans douleur thoracique. ${ }^{27}$ Une évaluation plus poussée peut mettre en évidence une hypertrophie ventriculaire ou de l'ischémie. Ces patients ont une réserve ventriculaire gauche diminuée et peuvent présenter des risques de fibrillation ventriculaire à cause de l'équilibre précaire entre la demande et l'apport d'oxygène. ${ }^{28}$ La conduite thérapeutique vise à maintenir la pression de perfusion coronaire et la contractilité du ventricule. Des vasopresseurs et des inotropes peuvent être nécessaires.

\section{Obstruction à l'éjection ventriculaire droite}

L'obstruction à l'éjection ventriculaire droite peut se produire à de multiples niveaux (Tableau IV). Les patients avec cette anomalie peuvent avoir un ventricule droit hypertendu, hypertrophié et sujet à l'ischémie. ${ }^{27}$ La présence d'une anomalie intra-cardiaque peut servir de soupape lorsque la pression du côté droit dépasse la pression du côté gauche comme la chose se produit chez les patients avec syndrome d'Eisenmenger ${ }^{23}$ Le but de la thérapie est de maintenir la perfusion coronaire et l'ino-
TABLEAU IV Obstruction à l'ejection ventriculaire droite et gauche

\begin{tabular}{ll}
\hline Gauche & Droite \\
\hline $\begin{array}{l}\text { Interruption de l'arc aortique } \\
\text { Coarctation de l'aorte }\end{array}$ & $\begin{array}{c}\text { Sténose de l'artère pulmonaire } \\
\text { Maladie vasculaire occlusive } \\
\text { pulmonaire }\end{array}$ \\
$\begin{array}{c}\text { Sténose aortique (sous } \\
\text { valvulaire, valvulaire, } \\
\text { supravalvulaire) } \\
\text { valvulaire, supravalvulaire) }\end{array}$ & $\begin{array}{c}\text { Tétralogie de Fallot } \\
\text { Synose et atrésie mitrale } \\
\text { hypoplasique }\end{array}$ \\
\hline
\end{tabular}

tropie du ventricule droit. La réduction de la post-charge ventriculaire peut être bénéfique. L'hypertension pulmonaire chez les patients avec maladie vasculaire occlusive représente une situation à haut risque. ${ }^{23,29} \mathrm{Ces}$ patients sont sujets à des augmentations aiguës et subites de la résistance vasculaire pulmonaire, ce qui peut amener une défaillance ventriculaire droite aiguë.. ${ }^{29}$ La conduite à tenir en présence de résistance vasculaire pulmonaire élevée est soulignée dans le Tableau III.

\section{Ischémie du myocarde}

L'étiologie de l'ischémie du myocarde chez les enfants avec maladies cardiaques congénitales est d'origine multiple. ${ }^{28}$ Comme chez les adultes, l'athérosclérose chez les enfants peut se produire dans plusieurs situations: dans certaines anomalies congénitales du métabolisme des lipides $^{30}$ et la progérie ${ }^{31,32}$ ou après la transplantation cardiaque. ${ }^{33}$ De façon générale cependant, l'ischémie du myocarde va se produire autant chez les enfants avec anomalie de perfusion (e.g., syndrome du coeur gauche hypoplasique), avec diminution de perfusion et de débit coronarien, et chez ceux qui ont des anomalies s'accompagnant d'hypoxémie chronique (lésions cyanogènes). ${ }^{34-37}$ L'aboutissement final, comme chez adultes, consiste en un déséquilibre entre l'apport et la demande d'oxygène. ${ }^{38}$

L'ischémie ventriculaire droite isolée se produit plus souvent chez les enfants à cause de la haute fréquence d'anomalies cardiaques droites. Le traitement du ventricule gauche ischémique en défaillance est semblable à ce qui se passe chez l'adulte, et consiste en une réduction de la post-charge et un support inotropique. Lorsque l'on traite une ischémie ventriculaire droite isolée, il faut inclure assez tôt dans le traitement des moyens d'augmenter la pression de perfusion coronaire avec des vasopresseurs et une optimalisation de la précharge. ${ }^{28}$

\section{Réponse au stress}

Chez les patients cyanosés, le mélange de sang intracardiaque ou le shunt dissocient la circulation droite et 
gauche, ce qui rend le couplage dynamique des échanges gazeux pulmonaires et cellulaires inefficaces ou impossibles. Ces patients font montre d'une adaptation lente au changement du taux de métabolisme, qui impose une dépendance anormale sur le métabolisme non-oxydatif. ${ }^{39,40} \mathrm{Il}$ n'est pas surprenant dès lors que les patients cyanosés ont tendance à développer une acidose autant respiratoire que métabolique en réponse au stress périopératoire, ce qui peut amener une prolongation de l'adaptation à, ou de récupération d'un niveau même faible de stress périopératoire. ${ }^{41-43}$

\section{Conduite de l'anesthésie}

\section{Prémédication}

On a recommandé la prémédication chez les enfants avec MCC pour minimiser l'anxiété due à la séparation des parents, de telle sorte que le patient sera calme et en sédation à l'arrivée en salle d'opération. La demande d'oxygène est ainsi réduite mais pas suffisamment pour causer de l'hypoventilation. Ce contrôle est particulièrement important chez les enfants cyanosés puisqu'une augmentation de l'anxiêté peut produire une désaturation importante. Même si la prémédication chez les enfants avec MCC est considérée sécuritaire, ${ }^{44,45}$ chez certains patients lourdement prémédiqués avec MCC cyanogène on a démontré des diminutions importantes de saturation artérielle lorsque les enfants demeurent non stimulés, ${ }^{44}$ possiblement à cause d'une réponse respiratoire diminuée à l'hypoxie. ${ }^{46}$ En conséquence, ces patients demandent une surveillance attentive et une oxygénation supplémentaire lorsqu'on leur donne une prémédication lourde. ${ }^{44}$

\section{Monitoring}

L'emplacement des conduits de mesures de pression artérielle pourra être influencé par la chirurgie antérieure. La pression artérielle chez les enfants qui ont déjà subi une procédure de Blalock-Taussig ou une chirurgie de coarctation de l'aorte ne devrait pas être mesurée du côté ipsilatéral à la chirurgie à cause d'une distorsion possible de l'artère sous-clavière. De même, chez les enfants qui ont déjà subi une chirurgie pour coarctation, la lecture distale de la pression artérielle peut sous-estimer la valeur obtenue au-dessus du site de chirurgie, si une sténose résiduelle et un gradient persistent.

Le protocole de base de surveillance de ces patients est celui prescrit par la Société Canadienne des Anesthésistes. ${ }^{47}$ La lecture de l'oxymétrie digitale chez les enfants peut être inexacte lorsqu'ils sont porteurs de MCC cyanogène ${ }^{48,49}$ Chez les patients avec saturation en hémoglobine inférieure à $80 \%$, plusieurs modèles d'oxymètres surestiment et d'autres sous-estiment la valeur réelle de la saturation artérielle en oxygène. ${ }^{48,49}$ Ces effets vont dépendre du modèle d'oxymètre digital. Le type d'hémoglobine présente chez le patient va aussi modifier la précision de l'oxymètre digital. Chez les nouveau-nés et les nourrissons, la présence d'hémoglobine foetale amène une surestimation de la valeur réelle de la saturation artérielle de l'hémoglobine en oxygène.

La mesure de la $\mathrm{PCO}_{2}$ en fin d'expiration donne un estimé précis de la pression partielle en $\mathrm{CO}_{2}$ artériel $\left(\mathrm{PaCO}_{2}\right)$ chez les enfants avec $\mathrm{MCC}$ non cyanogène, mais va sous-estimer de façon significative la $\mathrm{PaCO}_{2}$ chez les enfants avec MCC cyanogène. ${ }^{50,51}$

\section{Techniques anesthésiques}

Même si la plupart des enfants avec MCC tolèrent une anesthésie bien conduite, la capacité à tolérer les stress périopératoires associés à une chirurgie et une anesthésie majeure est réduite.

Aucune technique particulière ne peut être recommandée chez les enfants avec MCC. Des études ont montré qu'une anesthésie régionale ou générale bien menée peut être utilisée en sécurité chez tout patient avec MCC. ${ }^{6.752,53} \mathrm{La}$ technique doit être adaptée à chaque patient et doit tenir compte de la diminution de la réserve cardiovasculaire et aussi des problèmes potentiels.

\section{Conclusion}

La conduite de l'anesthésie sera sécuritaire chez la plupart des enfants avec maladie cardiaque congénitale si l'on comprend bien la physiopathologie de leurs lésions et les implications anesthésiques inhérentes. ${ }^{5}$ Cependant, des revues récentes de la morbidité liée à l' anesthésie montrent une incidence élevée des complications reliées à l'anesthésie chez les enfants avec maladie cardiaque congénitale. $^{6,7}$

\section{Références \\ (Voir page R64)}

